E International

Publicly Funded Passenger Transport Services in Finland

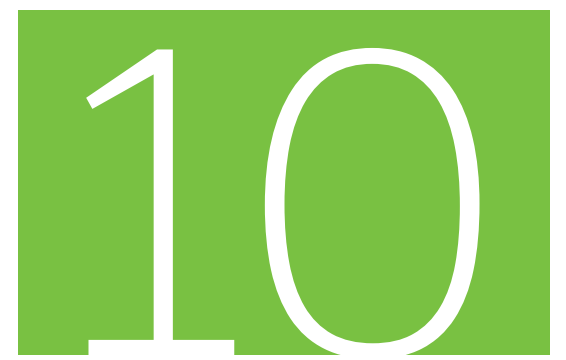

Discussion Paper 2015•10

Jari Kauppila

International Transport Forum, Paris, France 


\title{
Publicly funded passenger transport services in Finland
}

Discussion Paper No. 2015-10

\author{
Jari KAUPPILA
}

International Transport Forum, Paris

March 2015 


\section{THE INTERNATIONAL TRANSPORT FORUM}

The International Transport Forum at the OECD is an intergovernmental organisation with 54 member countries. It acts as a strategic think-tank, with the objective of helping shape the transport policy agenda on a global level and ensuring that it contributes to economic growth, environmental protection, social inclusion and the preservation of human life and well-being. The International Transport Forum organises an annual summit of Ministers along with leading representatives from industry, civil society and academia.

The International Transport Forum was created under a Declaration issued by the Council of Ministers of the ECMT (European Conference of Ministers of Transport) at its Ministerial Session in May 2006 under the legal authority of the Protocol of the ECMT, signed in Brussels on 17 October 1953, and legal instruments of the OECD.

The Members of the Forum are: Albania, Armenia, Australia, Austria, Azerbaijan, Belarus, Belgium, Bosnia and Herzegovina, Bulgaria, Canada, Chile, People's Republic of China, Croatia, Czech Republic, Denmark, Estonia, Finland, France, Former Yugoslav Republic of Macedonia, Georgia, Germany, Greece, Hungary, Iceland, India, Ireland, Italy, Japan, Korea, Latvia, Liechtenstein, Lithuania, Luxembourg, Malta, Mexico, Republic of Moldova, Montenegro, Netherlands, New Zealand, Norway, Poland, Portugal, Romania, Russian Federation, Serbia, Slovak Republic, Slovenia, Spain, Sweden, Switzerland, Turkey, Ukraine, United Kingdom and United States.

The International Transport Forum's Research Centre gathers statistics and conducts co-operative research programmes addressing all modes of transport. Its findings are widely disseminated and support policymaking in Member countries as well as contributing to the annual summit.

\section{Discussion Papers}

The International Transport Forum's Discussion Paper Series makes economic research, commissioned or carried out at its Research Centre, available to researchers and practitioners. The aim is to contribute to the understanding of the transport sector and to provide inputs to transport policy design.

ITF Discussion Papers should not be reported as representing the official views of the ITF or of its member countries. The opinions expressed and arguments employed are those of the authors.

Discussion Papers describe preliminary results or research in progress by the author(s) and are published to stimulate discussion on a broad range of issues on which the ITF works. Comments on Discussion Papers are welcomed, and may be sent to: International Transport Forum/OECD, 2 rue André-Pascal, 75775 Paris Cedex 16, France.

For further information on the Discussion Papers and other JTRC activities, please email: itf.contact@oecd.org

The Discussion Papers can be downloaded from: www.internationaltransportforum.org/jtrc/DiscussionPapers/jtrcpapers.html

The International Transport Forum's website is at: www.internationaltransportforum.org

This document and any map included herein are without prejudice to the status of or sovereignty over any territory, to the delimitation of international frontiers and boundaries and to the name of any territory, city or area. 


\section{Table of contents}

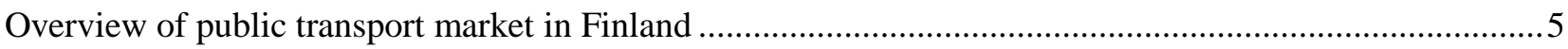

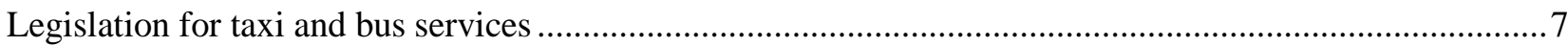

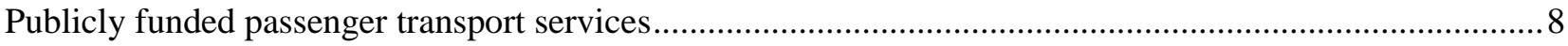

Government funded scheduled public transport and fair subsidies ........................................................ 9

Government purchase or reimbursement of school transport and travel for health care ..........................10

Municipal funded scheduled public transport and fair subsidies............................................................10

Municipal purchase or reimbursement of school transport............................................................. 11

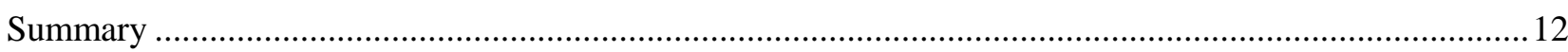

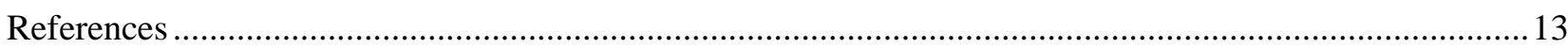





\section{Overview of public transport market in Finland}

The share of bus transport of total passenger transport (as a percentage of total inland passengerkilometres) is slightly above EU average in Finland. Buses account for around $10 \%$ of total passenger transport, compared with the EU average of $9 \%$ in 2011. The share of rail in total passenger transport, in turn, was $5 \%$ in 2011 , below the EU average of $7 \%$.

Over 590 million passengers used public transport services in Finland in 2011. Buses carried nearly $60 \%$ of total number of passengers. However, in passenger-kilometres buses accounted for $41 \%$ of the total 11718 million passenger-km, while railways accounted for $34 \%$.

Figure 1. Bus transport share of total passenger transport in selected countries, 2011 Percentage of passenger-km

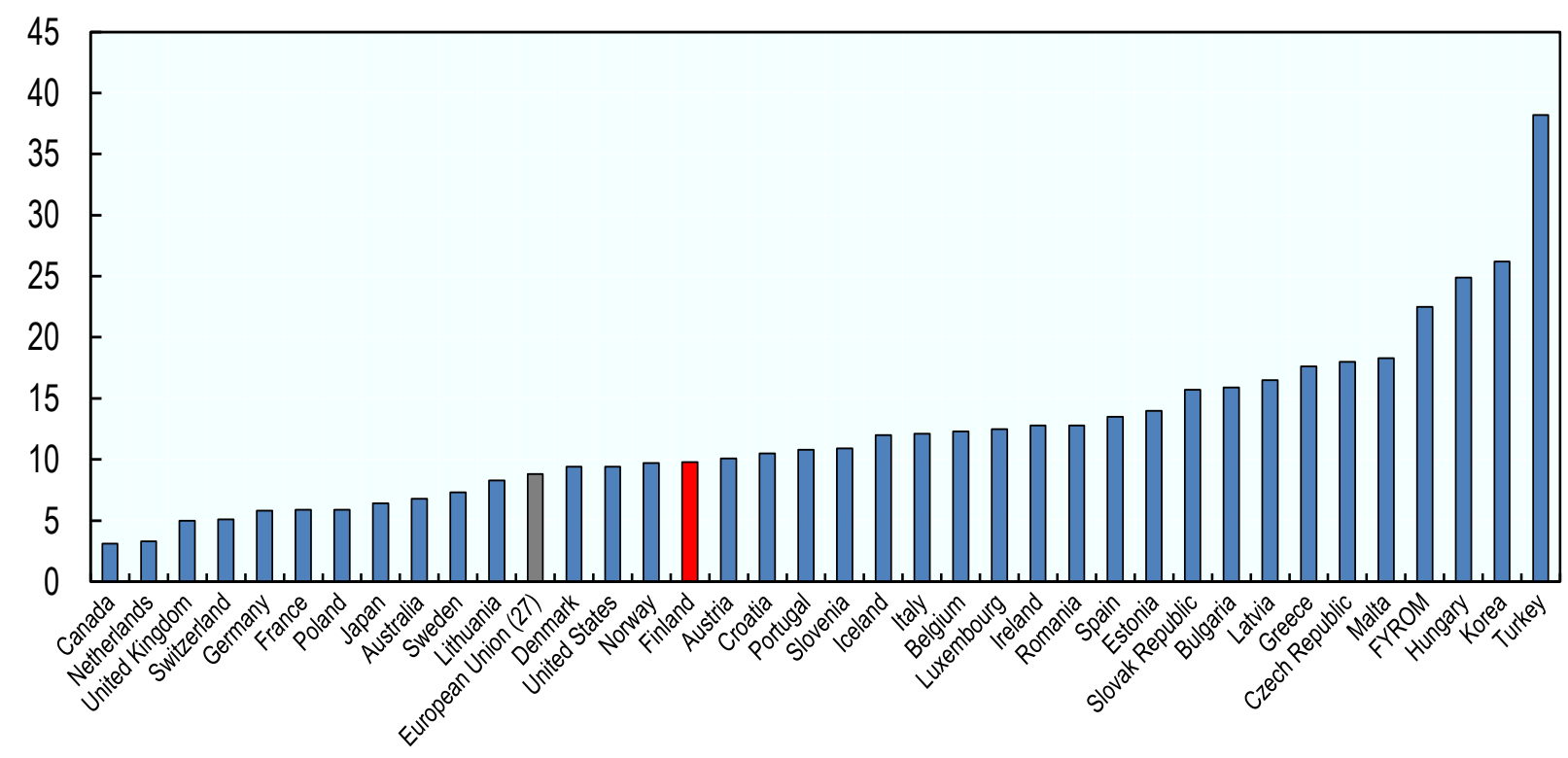

Source: ITF/OECD; Eurostat. 
Figure 2. Rail transport share of total passenger transport in selected countries, 2011

Percentage of passenger-km

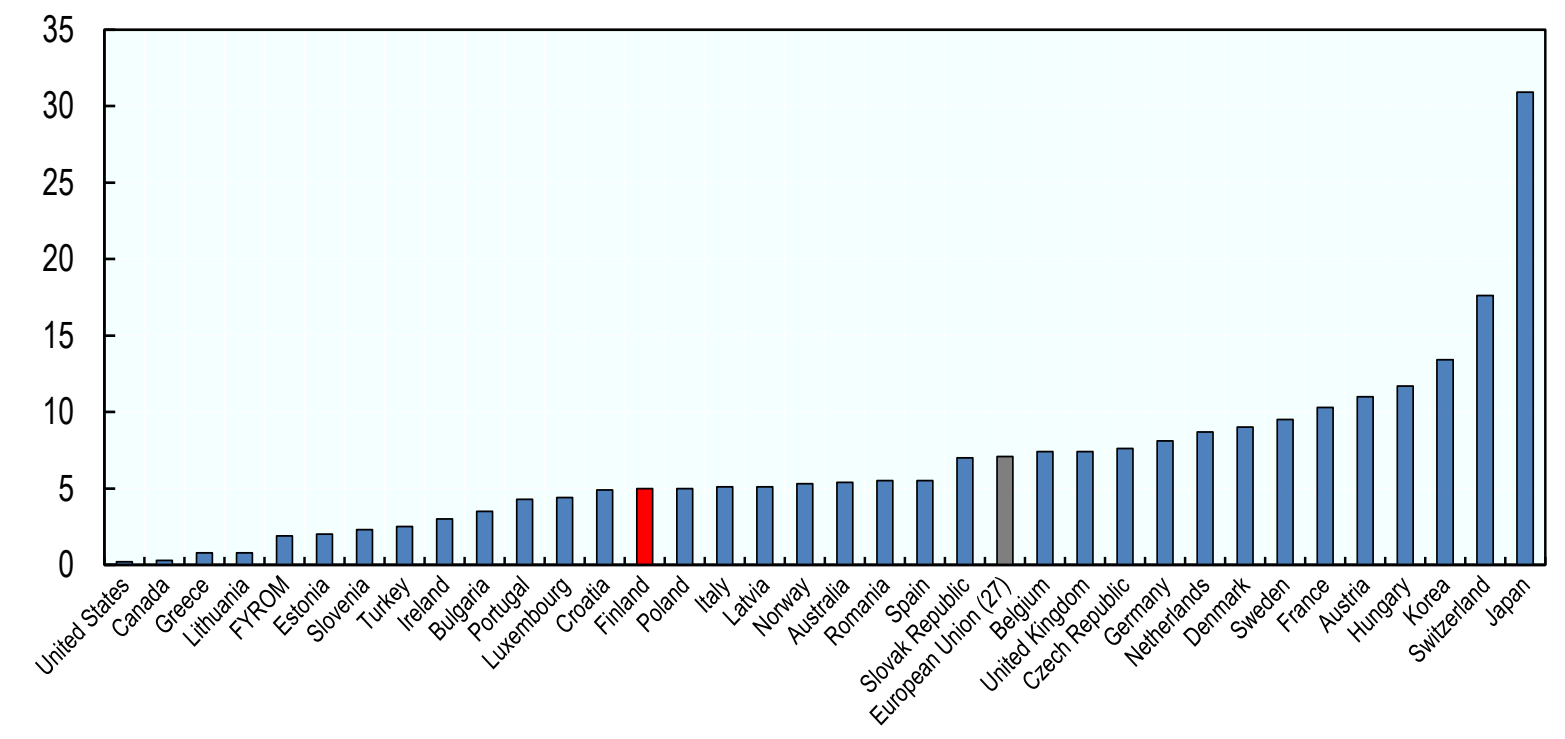

Source: ITF/OECD; Eurostat.

Figure 3. Market share of public transport in Finland in 2011

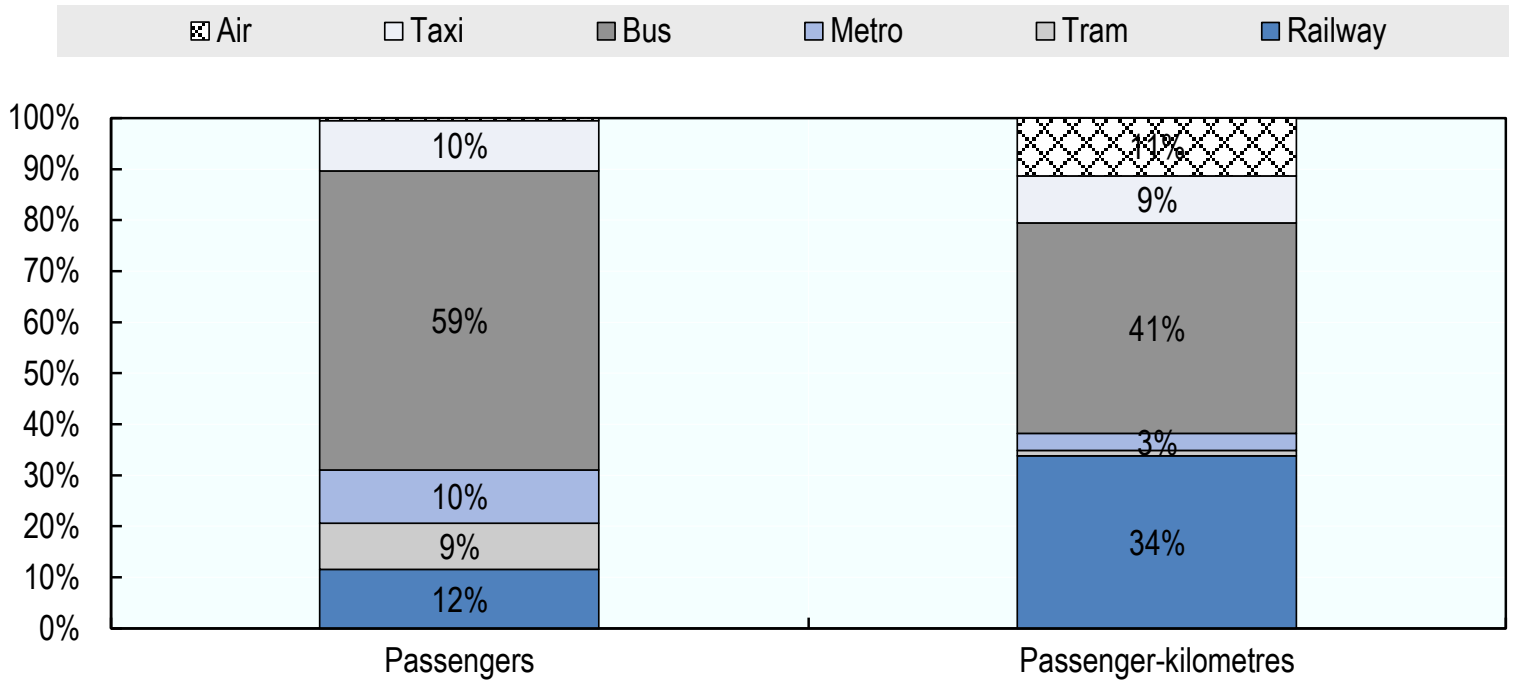

Source: Finnish Transport Agency, 2013.

Turnover of companies providing public transport services in Finland was 2932 million Euros in 2011 (Finnish Transport Agency, 2013). Bus transport companies and taxis accounted for the largest share, 1196 and 1019 million Euros, respectively. Of the total turnover, 523 million Euros (18\%) came from public transport services in major cities.

The following table presents the turnover of public transport industry by type of transport together with subsidies. Direct funding refers to purchases of transport by central and local government, state subsidies and the net amounts of deficit compensation for major cities. Reimbursement of transport expenses include compensation to and discounted tickets for special groups. Total general government subsidies for purchases of public transport accounted for nearly one billion Euros in 2011, resulting in over 33\% share of the sector's turnover. General government spending share of turnover was highest for taxi transport $(41 \%)$ followed by bus transport (40\%) and rail (19\%). The subsidy rate, calculated 
as the share of direct funding per turnover, was $12.6 \%$. In comparison, in the United Kingdom, around $20 \%$ of operating revenues for local bus services come from public funding (DfT, 2011).

Table 1. Turnover and subsidies for public transport in 2011

Million Euros

\begin{tabular}{|c|c|c|c|c|c|c|c|c|c|c|c|c|}
\hline & \multirow[t]{2}{*}{$\underline{\text { Turnover }}$} & \multicolumn{3}{|c|}{$\underline{\text { Central government }}$} & \multicolumn{3}{|c|}{ Local government } & \multicolumn{3}{|c|}{$\underline{\text { Total general government }}$} & \multirow[b]{2}{*}{$\begin{array}{l}\text { Share of } \\
\text { turnover }\end{array}$} & \multirow[b]{2}{*}{$\begin{array}{l}\text { Subsidy } \\
\text { rate }\end{array}$} \\
\hline & & $\begin{array}{l}\text { Direct } \\
\text { funding }\end{array}$ & $\begin{array}{l}\text { Reimburs } \\
\text { ement }\end{array}$ & Total & $\begin{array}{l}\text { Direct } \\
\text { funding }\end{array}$ & $\begin{array}{l}\text { Reimburs } \\
\text { ement }\end{array}$ & Total & $\begin{array}{l}\text { Direct } \\
\text { funding }\end{array}$ & $\begin{array}{l}\text { Reimburse } \\
\text { ment }\end{array}$ & Total & & \\
\hline Railway total & 421 & 45.6 & 5.1 & 50.8 & 26.2 & 3.8 & 30.1 & 71.9 & 9 & 80.8 & $19.2 \%$ & $17.1 \%$ \\
\hline $\begin{array}{l}\text { Long-distance } \\
\text { Helsinki }\end{array}$ & 320 & 34.7 & 3.6 & 38.3 & & & & 34.7 & 3.6 & 38.3 & $12.0 \%$ & $10.8 \%$ \\
\hline regional & 52 & 0.9 & & 0.9 & 26.2 & 1.8 & 28 & 27.1 & 1.8 & 28.9 & $55.6 \%$ & $52.1 \%$ \\
\hline Other Helsinki & 49 & 10.1 & 1.5 & 11.6 & & 2 & 2 & 10.1 & 3.5 & 13.7 & $28.0 \%$ & $20.6 \%$ \\
\hline Tram, metro & 75 & 2.2 & & 2.2 & -12.5 & 4.8 & -7.7 & -10.3 & 4.8 & -5.5 & & \\
\hline Bus total & 1196 & 48.7 & 39.4 & 88 & 255.4 & 133.9 & 389.3 & 304 & 173.3 & 477.3 & $39.9 \%$ & $25.4 \%$ \\
\hline Major cities & 347 & 5.9 & 0.2 & 6.1 & 165.8 & 9.2 & 175 & 171.7 & 9.4 & 181.1 & $52.2 \%$ & $49.5 \%$ \\
\hline Charter & 192 & 4.4 & 1.8 & 6.3 & & 55.2 & 55.2 & 4.4 & 57.1 & 61.5 & $32.0 \%$ & $2.3 \%$ \\
\hline Other bus & 656 & 38.3 & 37.3 & 75.6 & 89.6 & 69.5 & 159.1 & 127.9 & 106.8 & 234.7 & $35.8 \%$ & $19.5 \%$ \\
\hline Long-distance & 85 & & 5.6 & 5.6 & & & & 123.5 & 5.6 & 5.6 & $6.6 \%$ & \\
\hline Other route & 571 & 38.3 & 31.7 & 70 & 89.6 & 69.5 & 159.1 & 127.9 & 101.2 & 229.1 & $40.1 \%$ & $22.4 \%$ \\
\hline Taxi transport & 1019 & 2.9 & 160.9 & 163.8 & & 253.8 & 253.8 & 2.9 & 414.8 & 417.7 & $41.0 \%$ & $0.3 \%$ \\
\hline Air transport & 221 & 1.2 & 0.5 & 1.7 & 1.1 & & 1.1 & 2.3 & 0.5 & 2.8 & $1.3 \%$ & $1.0 \%$ \\
\hline TOTAL & 2932 & 100.6 & 205.9 & 306.5 & 270.2 & 396.4 & 666.6 & 370.8 & 602.3 & 973.1 & $33.2 \%$ & $12.6 \%$ \\
\hline
\end{tabular}

Source: Finnish Transport Agency, 2013.

\section{Legislation for taxi and bus services}

The Finnish Ministry of Transport and Communications prepares legislation regarding bus and coach transport as well as taxis. Bus transport in Finland is organised under the provisions of Public Transport Act (PTA), which is based on the Public Service Obligation (PSO) regulation of the European Union. The provision of professional passenger transport services in exchange for a payment is subject to a licence. The licence system is built on two licences: the basic licence is required in all kinds of public transport and entitles to operate general government purchased transport and private charter transport. For market-based transport and market-based demand-responsive transport there is also another licence required in addition to the basic licence.

Public bus transport can be organized either as a market-based system (no public financing) or procured according to the processes regulated by the PSO. The EU regulation on public service obligations establishes how public authorities may intervene in the market to guarantee the quantity and quality of public transport services. When authorities conclude contracts on the public procurement of public transport services, the provisions of the regulation and other legislation on public procurement must be observed.

Providing demand-responsive public transport services is also subject to a licence. The applicant must have a licence to operate public transport services and commit in providing services for a minimum of one year. 
In case of market-based charter transport with minibuses (capacity with max 16 persons), the PTA requires minimum five passengers per ride (source, Ministry of Transport and Communications).

Provisions on taxi services are laid down in the Taxi Act. The purpose of the Act is to ensure highquality taxi transport services throughout Finland. The maximum prices charged from customers for taxi services are established annually by government decree. Under the Taxi Act, the professional transport of people in passenger cars on public roads is subject to a licence granted by the local Centre for Economic Development, Transport and the Environment (so called ELY centre).

The owner of the taxi licence is obliged to provide taxi services primarily in the municipality for which the licence is granted. The ELY Centres confirm the maximum number of taxi licences per municipality on an annual basis (10 000 licences nationwide). The criteria for obtaining a licence are laid down in the Taxi Act. Examples of the criteria include that licence holders must have the professional skills necessary to provide taxi services and be able to meet their financial obligations.

In order to obtain a taxi driver's licence, applicants must complete compulsory training. The training requirements focus on traffic safety and the communication skills needed in customer service. The Act on the professional competence of taxi drivers entered into force at the beginning of 2010 . New taxi drivers applying for a licence are required to have completed at least 30 hours of training. In addition, they must demonstrate their knowledge of the local environment to the organiser of the training. The taxi driver's licence is valid for five years at a time. To renew his/her licence, a taxi driver must take part in further training lasting at least one day.

\section{Publicly funded passenger transport services}

There is no legal obligation to organise scheduled public transport services in Finland, except for school transport and certain travel for social welfare related purposes. Still, government as well as most regions and municipalities invest in providing these services as they are considered important part of the economic attractiveness and liveability of regions. A number of different authorities manage the administration, procurement and planning of a range of passenger transport services.

Publicly funded passenger transport services can be divided into two main categories:

1. Scheduled public transport (purchase of transport services and tariff subsidies); and

2. Purchase or reimbursement of school transport and travel for health care (paratransit).

In 2011, the total cost of publicly funded transport services amounted to 973 million Euros in Finland. This accounted for 33\% the total public transport industry turnover. Direct purchase of public transport services accounted for around 370 million Euros or $13 \%$ of total public transport turnover. Figures 4 and 5 present total funding of public transport by source of funding and by mode. Over $60 \%$ of funding is directed to municipal or government funding of direct purchase of transport services. Municipal purchases of transport services for school transport and travel for health care amount for the largest share, totalling nearly 400 million Euros (41\% of total). By mode, buses account for half of public funding while taxes account for $43 \%$ (MINTC, 2013b). 
Figure 4. Total funding of public transport by source of funding In Million 2011 Euros

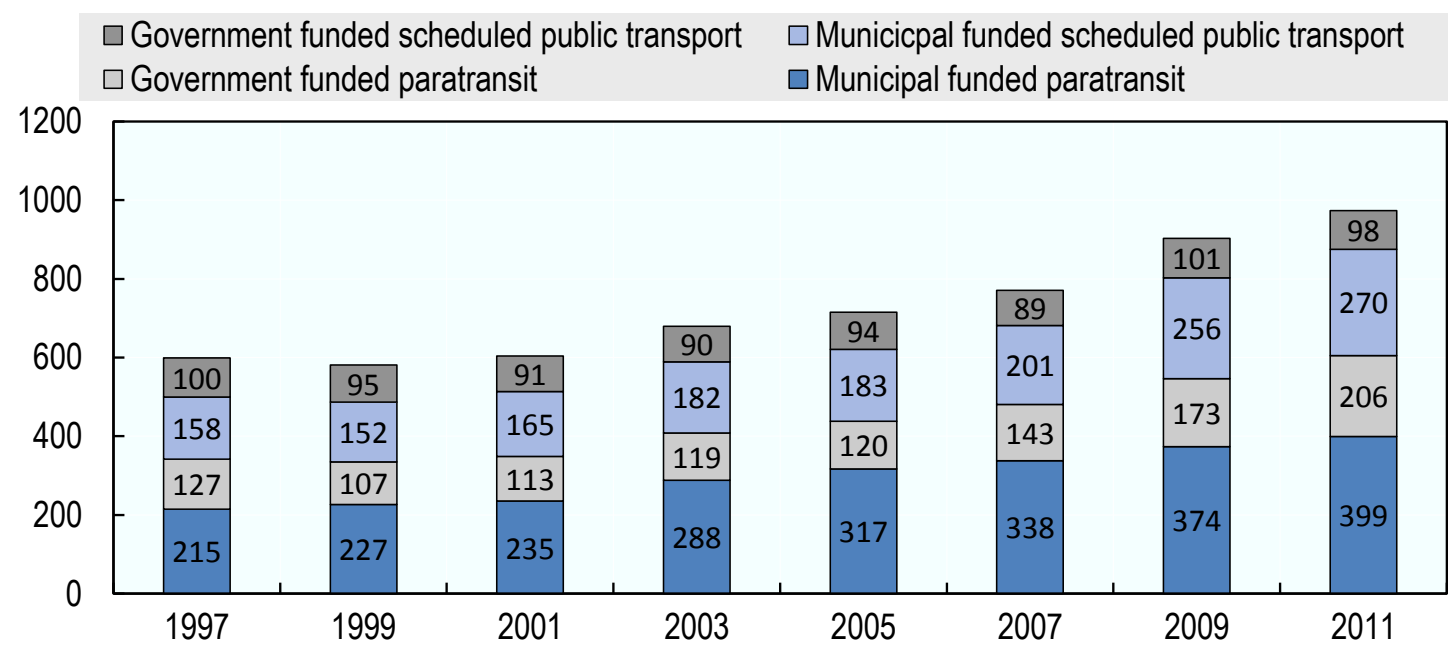

Source: MINTC, 2013b.

Figure 5. Total funding of public transport by mode In Million 2011 Euros

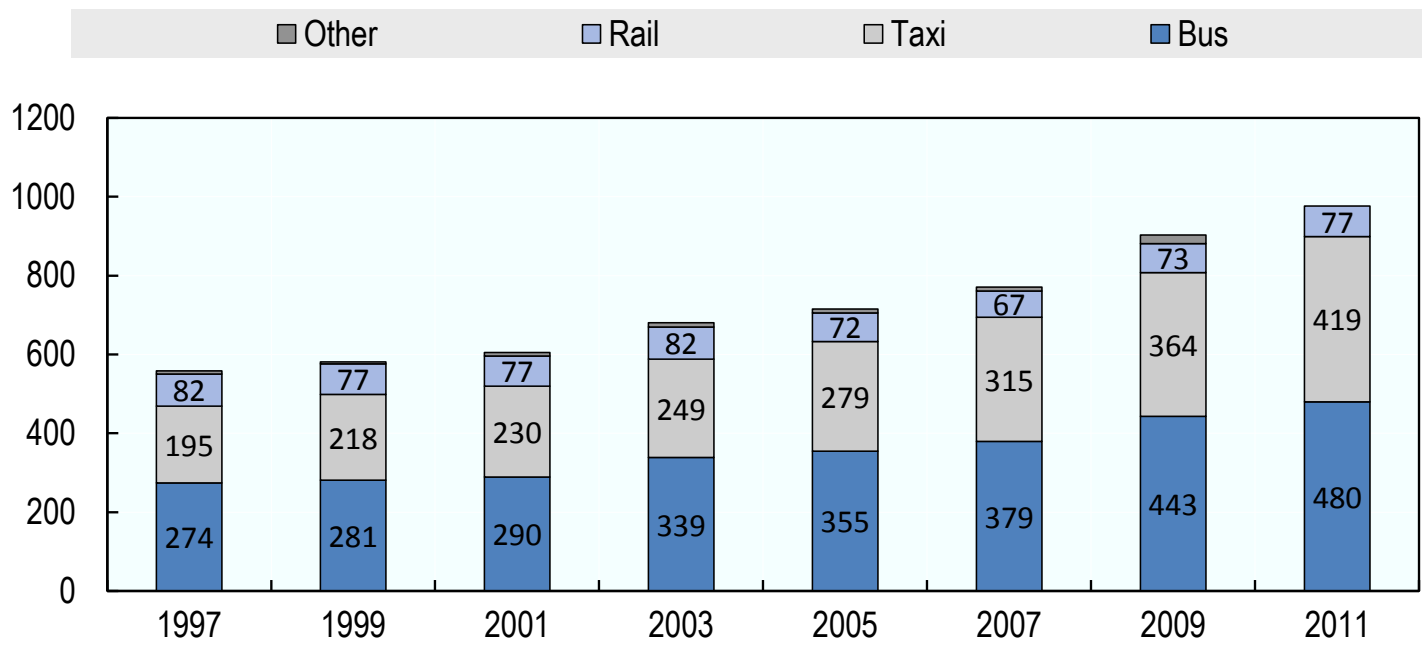

Source: MINTC, 2013b.

A more detailed description of general government direct funding and reimbursement is presented in the following for each type of service.

\section{Government funded scheduled public transport and fair subsidies}

Government funded scheduled public transport amounted 111 million Euros in the 2013 Government budget. Majority of the costs are related to the purchase of long distance train services for areas where market based services are not available (33.6 ME) and purchase of bus and taxi transport in rural areas, including subsidies for work travel (31.6 ME). In 2013, around 5.5 million passengers benefited from the bus transport in rural areas purchased by the government. The government subsidy is estimated at $4 €$ per bus passenger (Government Budget 2013). 
Government also subsidises public transport provision in large and medium-size cities for 20 million Euros. This subsidy is aimed at increasing the service level and competitiveness of public transport in cities.

\section{Government purchase or reimbursement of school transport and travel for health care}

Government reimbursements of travel costs for health care related travel are largely paid by the Finnish Social Insurance Institution (KELA). The objective is to provide access to (the nearest) health care services regardless of place of residence. The subsidy is significant especially to people living in rural areas and for those over 60 years old. The customer is responsible for costs up to $14.25 €$ per trip (or for an annual total of $242.25 €$ ) after which all costs will be reimbursed. These reimbursements amounted 294 million Euros corresponding to 5.3 million trips in 2013. Of the total trips, $60 \%$ were taken by taxi and $20 \%$ by own car. The cost per trip is slightly higher for taxis (53€/trip) than for private cars $(48 € /$ trip).

Table 2. Government reimbursement of travel costs for health care in 2013 Million Euros

\begin{tabular}{lrrrr}
\hline & Costs & Trips & \multicolumn{2}{c}{ Cost/trip } \\
\hline Taxi & 169 & 3.2 & 53 \\
Ambulance & 93 & 0.6 & 155 \\
Own car & 13 & 1.1 & 12 \\
Other & 19 & 0.4 & 48 \\
Total & $\mathbf{2 9 4}$ & $\mathbf{5 . 3}$ & \\
\hline
\end{tabular}

Source: Giss (2014)

Most of the health care districts have created a direct reimbursement system which allows also for combining trips. In this model, each health care district has a booking system that forwards the request to the nearest available taxi. All passengers travelling at the same time to the same direction will be combined in the same order. The total travel time should not become longer than double the original travel time due to combination of trips (and should not exceed 2 hours). The waiting time is maximum one hour. KELA has estimated that combining trips has already provided annual savings of 8 million Euros.

The Finnish Social Insurance Institution reimburses also school transport for upper secondary schools. This subsidy is eligible for trips over 10 kilometres long for daily school travel (minimum 4 days a week). These subsidies amounted to 48 million Euros in 2012 of which most (69\%) were reimbursements of travel by bus ( $€ 33$ million) while most of the remaining subsidies were for students using their own car for school trips. According to current legislation, the student is responsible for costs up to 43 euros per month while the subsidy covers the remaining costs. Number of students receiving the subsidy has remained constant at around 50000 since late 1990s. However, costs per passenger have increased significantly, from around 530 euros/student in 1998 to 865 euros /student in 2012.

\section{Municipal funded scheduled public transport and fair subsidies}

Municipalities subsidy local public transport with varying degree. Direct funding of scheduled public transport by municipalities amounted 270 million Euros in 2011. Of this, main part (155 million Euros) includes public transport provision in Helsinki metropolitan area. Purchase of scheduled public transport in small cities totalled 85 million Euros. 


\section{Municipal purchase or reimbursement of school transport}

School transport for elementary and secondary school accounts for the largest share of municipal travel costs, amounting to 160 million Euros in 2011. These include tickets for scheduled bus services as well as bus and taxi services purchased separately by municipalities. The provision of school transport is laid down in a law according to which it is the obligation of the municipality to organize school transport for all students whose trip is more than five kilometres.

The number of students eligible for school transport has remained relatively constant at around $23 \%$ of total over the years. However, costs per students have increased from 953 euros per student in 2005 to 1426 euros in 2012. Other municipal obligations include the responsibility for organising transport services for those with limited access due to illness or handicap. These transport services amounted at 112 million Euros in 2011. In addition to those set by legislation, municipalities organised other discretionary transport services for other social welfare purpose amounting 28 million Euros (MINTC, 2013b).

Figure 6. Number of students and total costs

Euros (constant 2012 values)

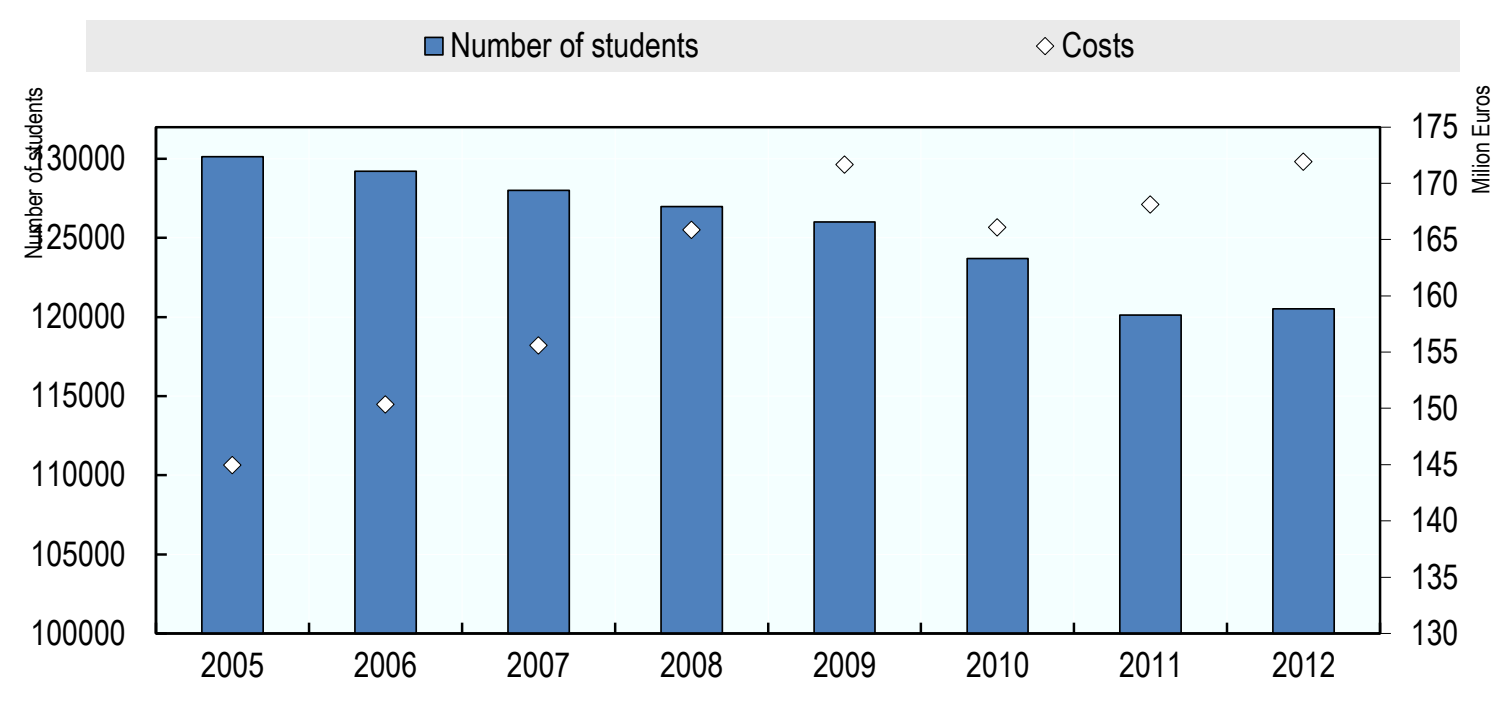

Source: Karvonen \& Siltala, 2014. 
Figure 7. Cost per student

Euros (constant 2012 values)

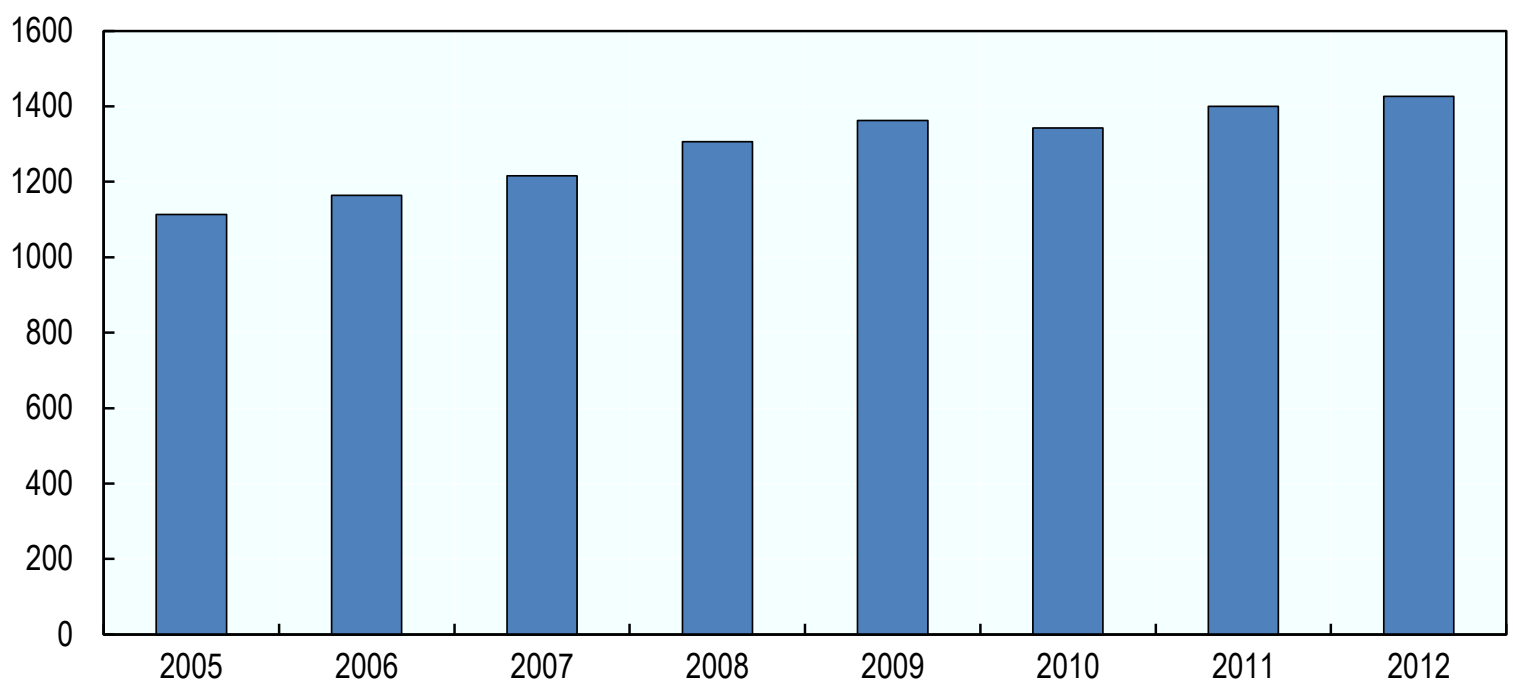

Source: Karvonen \& Siltala, 2014.

\section{Summary}

In Finland, passenger transport services funded from public resources are not the responsibility of a single authority. Instead, a number of different authorities manage the administration, procurement and planning of a range of passenger transport services. In 2012, the Ministry of Transport and Communications appointed a rapporteur to examine whether publicly funded passenger transport services could be combined. The report concluded that there is a considerable savings potential, especially with more efficient procurement and planning of transport services (MINTC, 2013a). Reimbursement are estimated to total EUR 900 million by 2030, instead of projected EUR 1.4 billion through concentration of the administration and financing of passenger services for one authority, taking more advantage of the combination of different kinds of trips and encouraging passengers and authorities to organise their trips in a more efficient way.

Despite efforts to maintain high level of services, accessibility is becoming an issue in rural areas and especially people with limited access have seen their service levels reduced in Finland. At the same time, the cost of publicly funded passenger transport services is estimated to increasing around $10 \%$ per year. Several factors have been identified for this cost increase, including:

- General cost increase in producing transport services;

- Growth in purchase of statutory travel services (provided often by taxi) in rural areas and even in cities as a result of a decline in market based service levels, combined with reduced public funds for public transport;

- Cooperation for procurement of transport services within and between municipalities and regional authorities not optimal; 
- Transport services are not being planned as a whole but each administration works on its own silo;

- Goods, people and services are moving separately;

- Procurement of taxi services not working very well as authorities lack knowledge;

- Taxi licenses are based on quotas and prices are controlled while often only one taxi operator per region resulting with little competition;

- Increase in costs related to school transport as a result of closing down of several schools in rural areas, resulting in longer distance for school travel; and

- Ageing of the society and simultaneous reduction of services for elderly in rural areas, resulting with increased distances for health care services.

\section{References}

Finnish Transport Agency (2013), Public Transport Performance Statistics 2011, Statistics of the Finnish Transport Agency, 3-2013, available at http://www2.liikennevirasto.fi/julkaisut/pdf3/lti 201303_public_transport_web.pdf

Giss (2014), Taksien suorakorvausmenettely, matkojen yhdistely, KELA, 13.1.2014, Power Point.

Government Budget (2013), available at http://budjetti.vm.fi/indox/tae/frame_year.jsp?year=2013\&lang=fi

Heikura (2014), Kelan taksikyytien suorakorvausmenettely, matkojen yhdistely Keski-Suomen sairaanhoitopiirissä, 13.1.2014, Power Point.

Kuusisto (2014), Koulumatkatukea toisen asteen opiskelijoille, KELA, 13.1.2014, Power point.

Karvonen \& Siltala (2014), Koululaisten kuljetuksista, Kuntaliitto, 18.2.2014, Power Point.

MINTC (2013a), Julkisesti tuettujen henkilökuljetusten rahoituksen ja toimintatapojen kehittäminen, Liikenne- ja viestintäministeriön julkaisuja 11-2013.

MINTC (2013b), Joukkoliikenteen rahoitus, Työryhmän raportti, Liikenne- ja viestintäministeriön julkaisuja 12-2013. 
